Historic, Archive Document

Do not assume content reflects current scientific knowledge, policies, or practices. 



\section{Flowering Plants}

ICHYRANTHES, Brightest Red, and McNally, (Yellow and Green) rooted cuttings, $\$ 1.50$ per $100 ; 21$-4-in. 4c each.

AGERATUM, Little Blue Star and Swanley Strong rooted cuttings, $\$ 1.25$ per $100, \$ 12.00$ per $1000,21-4$-in $\$ 4.00$ per 100 .

ALTERNANTHERAS. Red, Yellow and Green and Brilliancy rooted cuttings, $\$ 1.25, \$ 10.00$ per $1000 ; 2$ 1-4-in., $\$ 4.00$ per 100 .

ALYSSUMS. Double Sweet; rooted cuttings, $\$ 1.25$, $\$ 10.00$ per $1000 ; 21 / 4$-in., $\$ 3.00^{\prime}$ per 100 .

ARTILLERY PLANTS. Rooted cuttings, 2c; $2 \frac{1}{4}$-in., 5c. ASTERS, Queen of Market, and Comet 4 colors seedlings $.75 \mathrm{c}$ per, T. P. $\$ 1.50$.

BEGONIAS. Erfordii, rooted cuttings, $2 c$; fine and bushy $2 \frac{1}{4}$-in., $\$ 700 ; 3$-in., $\$ 12.00 ; 4$-in., $\$ 15.00$ per 100 .

BENCH ROSE-Bushes, $10 \mathrm{c}$

CALENDULAS BAILS, Strain strong seedlings $.75 \mathrm{c}$ transplanted, $\$ 1.50$ per $100,2 \frac{1}{4}$-in., $\$ 5.00$.

CANNAS. Assorted, 2 to 3-eye roots, \$4.00 per 100.

CARNATION ROOTED CUTTINGS-Rose Pink Enchantress, Pink Enchantress, White Matchless, R. C. $\$ 3.00$ per 1002 1-4-in. Pot 5c.

COBAEAS SCANDENS or Cathedral Bells, $2 \frac{1}{4}$-in., vines staked 18-in high, .06c.

CENTAUREAS or Dusty Miller $2 \frac{1 / 4}{4}$-in., $\$ 5.00$ per 100 .

CHRYSANTHEMUMS. Diana, extra fine white pompon, Yellow Climax and Bronze rooted cuttings, $\$ 3.00$ per $10021-4$ in $\$ 5.00$

COLEUS. Trailing Queen, Golden Bedder, Bonfire Brilliiancy, President Harding, Glory of Autumn, Verschaffeltii, Red Cloud Empress of Japan, Mrs. Turner rooted cuttings, $\$ 1.50 ; 2$ 1-4-in, $\$ 4.00 ; 3$-in., $\$ 8.00$ per 100 .

D.AISIES. Marguerite, white with yellow center; strong rooted cuttings, $\$ 2.00, \$ 15.00$ per $1000 ; 21 / 4-$ in., $\$ 4.00$ per 100.

ENGLISH IVY. Hardy rooted cuttings, $\$ 2.00 ; 2 \frac{1}{4}$-in., $\$ 5.00$ per 100 .
FERNS. Boston, $2 \frac{1}{4}$-in., at $.07 \frac{1}{2} ; 3$-in at $.15 \mathrm{c} ; 4$-in at $.25 \mathrm{c}$; Asparagus Plumosus 4 -in at $20 \mathrm{c}$.

FUCHSIAS. Best varieties, good assortment, $21 / 4$-in. $\$ 5.00$ pel 100 ; rooted cuttings, $\$ 2.00$ per 100 .

GLRANIUMS. Snow Queen, largest white and General Grant-best Scarlet rooted cuttings, $\$ 2.50$; 2 1-2-in., $\$ 5.00 ; 3$-in., $\$ 10.00 ; 4$-in., $\$ 15.00$ per 100. Mme. Salleroi, R. C. .02e 2 1-4-in., $\$ 5.00$ per 100. Geraniums, any variety, 4-in., $\$ 15.00 \mathrm{per} 100$. Rose and Elk-horn-leaved, rooted cuttings, $\$ 2.50 ; 3$-in $\$ 10.00$ per 100 .

GERMAN OR PARLOR, Ivy, rooted cuttings, $\$ 1.50$; 2 1-4-in., $\$ 4.00$ per 100.

HELIOTROPES. Rooted cuttings, $\$ 1.50 ; 21 / 4-i n ., 4 \mathrm{c}$.

IMPATIENS, Sultana, Pink and Salmon R. C. .02c, 2 1-4 in., at .04c; 3 -in at $.10 \mathrm{c}$.

PANSY PLANTS-Extra strong Vaughan's International seedlings $\$ 10.00$ per 1000 Transplanted $\$ 15.00$ per 1000 PJuargoniums. Easter Greeting, rooted cuttings, $\$ 5.00$ per $100 ; 21 / 4$-in., $\$ 8.00 ; 3$-in., $\$ 12.00 ; 4$-in., $\$ 20.00$ per 100.

PETUNIAS. Vaughans, Double fringed. Assorted 21/4-in., at $.05 \mathrm{c}$

I'ILEAS. Artillery Plant, strong R. C. $02 \mathrm{c} ; 21 / 4$-in., at 5c.

SALVIA SPLENDENS OR BONFIRE rooted cuttings, $\$ 1.50 ; \$ 12.00$ per $1000 ; 21-4-$ in., $\$ 4.00$ per 100 .

SNAPDRAGONS. Giant flowers. Pink, White, Lavender, Red and Yellow, R. C. .02c, 2 1-4-in., $\$ 5.00$ per 100 .

sToCKs. Cut and come again. Pink, White and Red. Strong seedlings, $\$ 1.00$ per $100,2 \frac{1}{4}-$ in., $4 \mathrm{c}$.

SANTOLINAS R. C. .02c; 21-4 in at .05, 3-in. $10 \mathrm{c}$.

SWAINSONIA, Alba, R. C. at 2c, $2 \frac{1}{4}-$-in., at $7 \mathrm{c}$.

TRADESCANTIAS. Tricolor and Green, rooted cuttings $\$ 1.25 ; 21 / 4-$ in., $3 \mathrm{c}$.

VERBENA. Vaughans Mammoth Mixture, strong Transplanted $\$ 1.50$ per $10021-4$ in co 4

VrNCAS, Variegated and Green; rooted cuttings, $\$ 1.50$ 2 1-2-in., $\$ 5.00 ; 3$-in., $\$ 10.00$ per 100 . 4 -in $\$ 15.00$

\section{Vegetable Plants}

LETTCCE. Grand Rapids; seedlings, $\$ 2.00$ per 1000 ; transplanted, $\$ 4.00$ per 1000 .

TOMATOES. Any quantity, best varieties, well rooted Bonny Best and John Baer plants, strong seedlings $\$ 4.00$ per 1000 ; transplanted, $\$ 8.00$ per 1000 Potted 2 1-4-in., at .03c each.

CABBAGE. Early Copenhagen and Early Jersey Wakefield; strong plants, well rooted seedlings, $\$ 3.00$ per 1000 ; transplanted, $\$ 6.00 \mathrm{per}^{\circ} 1000$.

RUST PROOF WASHINGTON AND PAIMETTO ASPARAGUS ROOTS, 2 yr. old, $\$ 1.00$ per $100 ; \$ 8.00$ per 1000 .
PEPPERS. Large Bell, strong rooted seedlings, $\$ 5.00$ per 1000 ; transplanted, $\$ 8.00$ per 1000 .

EGGPLANTS. New York Improved Strong rooted seedlings, $\$ 5.00$ per 1000 ; transplanted, $\$ 8.00$ per 1000 .

STRA WBERRY PIANTS. Progressive Everbearing, $\$ 1.50$ per $100 ; \$ 14.00$ per 1000 ; Senator Dunlap, Klondyke and Brandywine, $\$ 1.00$ per $100 ; \$ 6.00$ per 1000 .

CAULIFLOWER, Strong plants, well rooted Early Snowball seedlings, $\$ 5.00$ per 1000 ; transplanted, $\$ 8.00$ per 1000 . 


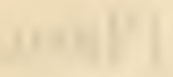

